\title{
Increasing of the carbide cutting tool life by developing the multilayer coatings
}

\author{
Vladimir Tabakov ${ }^{1}$, Aleksey Chikhranov ${ }^{1, *}$, and Sergei Sizov ${ }^{1}$ \\ ${ }^{1}$ Federal State Budgetary Educational Institution of Higher Education Ulyanovsk State University, Ulyanovsk, Russian Federation \\ ${ }^{2}$ Joint-Stock Company Ulyanovsk Design Bureau of Instrumentation, Ulyanovsk, Russian Federation
}

\begin{abstract}
The paper presents the results of studying the structural parameters and mechanical properties of multi-element coatings based on-TiZrN, TiZrAlN, TiZrCrN, and TiNbAlN. The phase composition, the structural parameters, and the mechanical properties of such coatings are shown to depend on the design of cathode evaporators and the machine layout at the moment of application. Compared to TiN coating, multielement coatings have higher residual compressive stress, smaller CSR, higher microdeformations of the crystal lattice, better mechanical properties, yet weaker adhesion to the tool base. Based on studying their structural parameters and mechanical properties, we have designed double-layer coatings. Use of such multi-layer coatings prolongs the tool life of carbide plates compared to TiN coating.
\end{abstract}

\section{Introduction}

Multi-layer coatings are increasingly used to improve the efficiency of cutters [1-4]. The efficiency of such coatings depends on the mechanical properties of individual layers with specific functions $[5,6]$. The mechanical properties of coatings depend on their deposition. Changing the layout of the machine and the design of cathodes has a significant impact on the mechanical properties of coatings [7-13]. Therefore, by changing the deposition conditions, we can adjust the properties of multi-layer coatings.

This research is to improve the efficiency of carbide tools by adjusting the layer-specific composition of multi-layer coatings.

\section{Methodology of Experiment}

Durable coatings were applied to MK8 carbide plates using a Bulat-6 machine. The chemical composition of such coatings was identified by quantitative X-ray analysis on a MAP-4 machine with ZAF adjustments being factored in. The parameters of the coating structure (lattice spacing $a$, half-width of the X-ray diffractive line $\beta_{111}$ ) and the residual compressive stresses $\sigma_{0}$ were studied by means of a ДРОН-3M diffractometer; relative microdeformations of the crystal lattice $\Delta a / a$ and the coherent scattering regions (CSR) $D$ were calculated as in [14]. Microhardness $H_{\mu}$, first-kind elasticity modulus $E$, fracture toughness $K_{I C I}$ were determined as in [15]. The adhesion strength was evaluated on the bases of the stratification coefficient calculated using a TK-2M hardness tester as in [1]. The efficiency of MK8 carbide plates was evaluated based on the tool life when turning workpieces made of $38 \mathrm{XГH}$ steel.

\section{Methodology of Experiment}

The multi-layer coating architecture has been selected based on their application in continuous turning as recommended in $[2,6,16]$. According to those papers, the upper layer should create favorable interaction of machined and tool materials at the front surface of the cutter to lower equivalent stresses and stabilize the shape of the cutting wedge. At the same time, in order to contain the fracturing processes, it is desirable that this layer has high mechanical properties as well as high level of its own residual compressive stress that contribute to the generation of higher normal compressive stresses during the cutting. As shown in [2, 4], multi-element coatings, i.e. three-element coatings based on modified titanium nitride, are the best when it comes to meeting such requirements. Beside the above requirements, coatings should have strong adhesion to the tool base; single-element coatings are adhesionstronger than their multi-element counterparts [1,2].

Based on the above, we studied TiN, TiZrN, TiZrAlN, TiZrCrN and TiNbAlN which were then used as layers in multi-layer coatings. TiZrN coatings were applied by two cathodes of titanium and zirconium located opposite to each other; TiZrAlN was applied by the same cathodes plus a cathode made of a titanaluminum alloy. TiNbAIN was applied by two titanium cathodes plus a titan-niobium-aluminum cathode; TiZrCrN was applied by composite cathodes: two titanium cathodes with zirconium inserts and one titanium cathode with a chromium insert. Table 1 presents the chemical composition of the coatings.

\footnotetext{
"Corresponding author: chihranov@mail.ru
} 
Table 1. Chemical composition of coatings.

\begin{tabular}{|c|c|c|c|c|c|}
\hline \multirow{2}{*}{ Coating } & \multicolumn{5}{|c|}{ Elements in the coating } \\
\cline { 2 - 6 } & $\mathrm{Ti}$ & $\mathrm{Zr}$ & $\mathrm{Cr}$ & $\mathrm{Nb}$ & $\mathrm{Al}$ \\
\hline TiZrN & 57.2 & 42.8 & - & - & - \\
\hline TiZrAlN & 57.5 & 39.75 & - & - & 2.8 \\
\hline TiNbAlN & 83.4 & - & - & 14.5 & 2.1 \\
\hline TiZrCrN & 75.4 & 13.4 & 11.2 & - & - \\
\hline
\end{tabular}

TiZrN and TiZrAlN are biphasic coatings. TiZrN diffraction pattern in shown in Figure 1a. As shown there, there are two diffraction peaks that are identified as $\mathrm{TiN}$ (111) and $\mathrm{ZrN}$ (111), both having a cubic crystal lattice. At an angle of $2 \theta=35.2$ grad. between them, there is a diffraction peak identifiable as solid TiZrN solution (111). According $[6,15]$, such coatings have a multilayer structure where the multi-layers of separate phases and the solid solution alternate to improve the mechanical properties. TiNbAlN and TiZrCrN are uniphasic coatings. The diffraction patterns of these coatings (see Figure 1b) only show one high-intensity diffraction peak identifiable as TiN (111). Being uniphasic proves the homogeneity of such coatings and lack of multi-layer structure.

Table 2 presents the results of studying the structural parameters of multi-element coatings compated to TiN.

Table 2. Structural parameters and mechanical properties.

\begin{tabular}{|c|c|c|c|c|c|}
\hline Coating & TiN & TiZrN & TiZrAIN & TiNbAIN & TiZrCrN \\
\hline$a, \mathrm{~nm}$ & 0.4335 & 0.4356 & 0.4344 & 0.4309 & 0.4279 \\
\hline$\beta_{111}, \mathrm{deg}$ & 0.40 & 0.82 & 1.06 & 0.70 & 0.59 \\
\hline$\sigma_{o}, \mathrm{MPa}$ & -775 & -1352 & -1487 & -1875 & -1422 \\
\hline$D, \mathrm{~nm}$ & 26.0 & 11.63 & 8.90 & 13.70 & 16.56 \\
\hline$\Delta a / a 10^{-3}$ & 4.8 & 10.6 & 13.8 & 9.1 & 7.5 \\
\hline$H_{\mu}, \mathrm{GPa}$ & 24.2 & 36.0 & 39.8 & 37.6 & 36.8 \\
\hline \begin{tabular}{c}
$E, \mathrm{GPa}$ \\
\hline$K_{I C}, \mathrm{MPa}^{1 / 2}$
\end{tabular} & 8.24 & 8.73 & 12.32 & 11.73 & 10.35 \\
\hline$K_{O}$ & 0 & 0.08 & 0.61 & 0.13 & 1.57 \\
\hline $\begin{array}{c}H_{\mu}{ }^{3} / E^{2}, \\
\mathrm{GPa}\end{array}$ & 0.143 & 0.315 & 0.351 & 0.329 & 0.304 \\
\hline
\end{tabular}

It is found out that compared to TiN, multi-element coatings have a greated X-ray line half-width, greater residual compressive stresses, smaller CSR, and greater relative microdeformations of the crystal lattice. Comparing bi- and tri-element coatings shows that the latter have higher residual compressive stresses, whereas TiNbAlN has the greatest value of $\sigma_{\mathrm{o}}$.

The half-width of the X-ray line depends on the design of cathodes and the layout of the machine used to apply the coating. $\beta_{111}$ is at highest for TiZrAlN applied with solid titanium and zirconium cathodes; such coatings have a multi-layer stucture. The absence of thereof in $\mathrm{TiZrCrN}$ is what results in lower $\beta_{111}$. These data accord to what is described in $[6,16]$. Multi-layer TiZrAlN coatings also have the smallest SCR $D$ and the greatest value of $\Delta a / a$.

Multi-element coatings have higher mechanical properties compated to $\mathrm{TiN}$, see Table 2. Their microhardness is 1.48-1.64 times higher, and the modulus of elasticity is 1.2-1.35 times higher depending on the composition. Tri-element coatings have higher microhardness, modulus of elasticity, and fracture toughness, but lower adhesion strength compared to bielement coatings. TiZrCrN have the least adhesion strength, whereas its stratification coefficient is considerably higher than that of other three-element coatings. Multi-element coatings do not differ significantly in terms of resistance to plastic deformation (the ratio $H_{\mu}{ }^{3} / E^{2}$ ). These data are in line with what is described in $[6,16]$, which is due to the effect of various mechanisms strengthening the material upon their condensation.
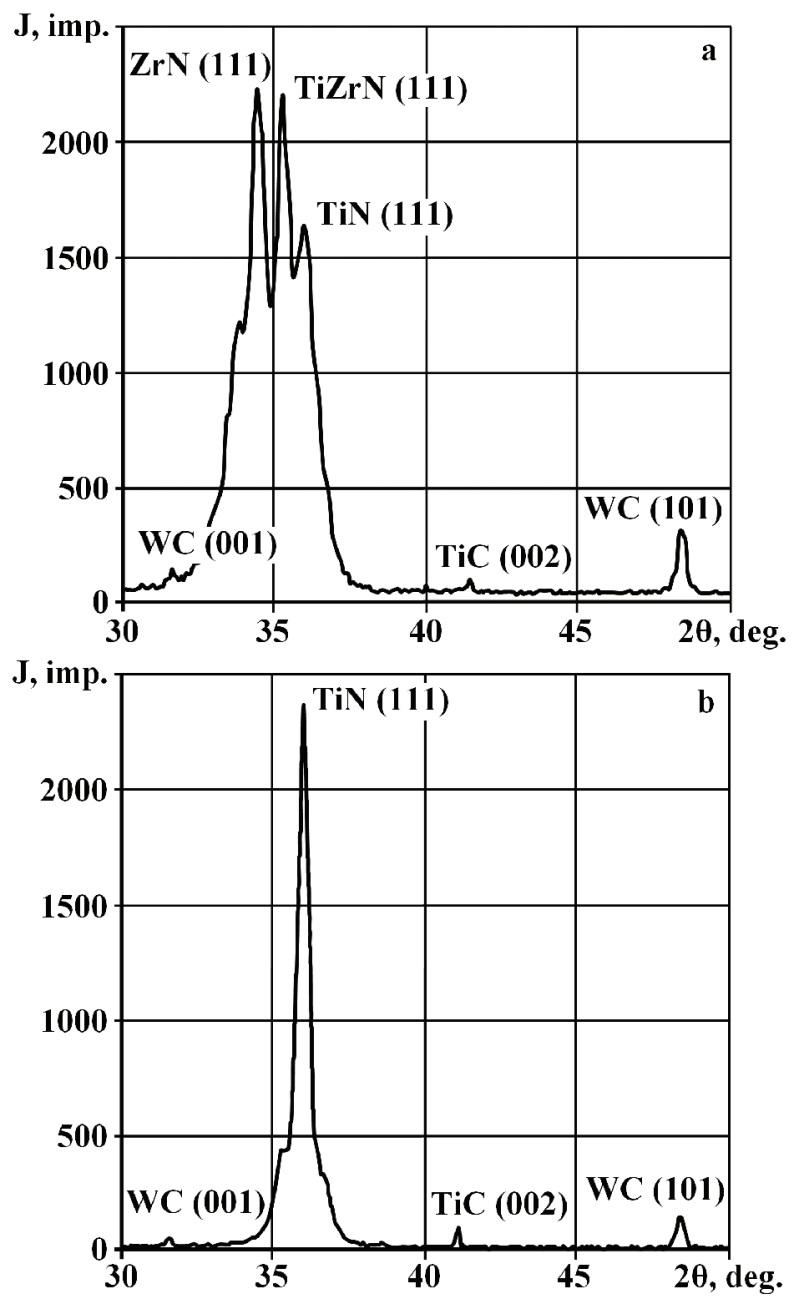

Fig. 1. Fragments of TiZrN (a) and TiNbAlN (b) diffraction patterns

Analyzing the results of studies, we note that TiZrN coatings have the greatest adhesion strength, whereas TiNbAlN and TiZrAlN boast the best combination of 
mechanical properties and residual stresses to generate higher normal compressive stress during cutting.

Based on these data and the principle of how multilayer coatings are formed for continuous cutting, we have developed double-layer coatings where the lower level is TiZrN and the upper level is TiNbAlN, TiZrAlN, TiZrCrN. The efficiency thereof was tested by turning $38 \mathrm{XГH}$ steel workpieces. Figure 2 presents the results.

It has been found out that use of our bi-layer coatings prolongs the tool life of carbide plates 1.8-2.8 times compared to TiN (the exact value depends on the cutting parameters and the material machined). In such terms, the most efficient coating is the double-layer with a TiNbAlN upper layer, the least efficient is that with TiZrCrN upper layer. TiZrN-TiZrCrN being less efficient is due to the lower adhesion strength of the lower layer as well as due to lower mechanical properties and residual compressive stresses characteristic of coatings made by composite cathodes $[1,2]$.
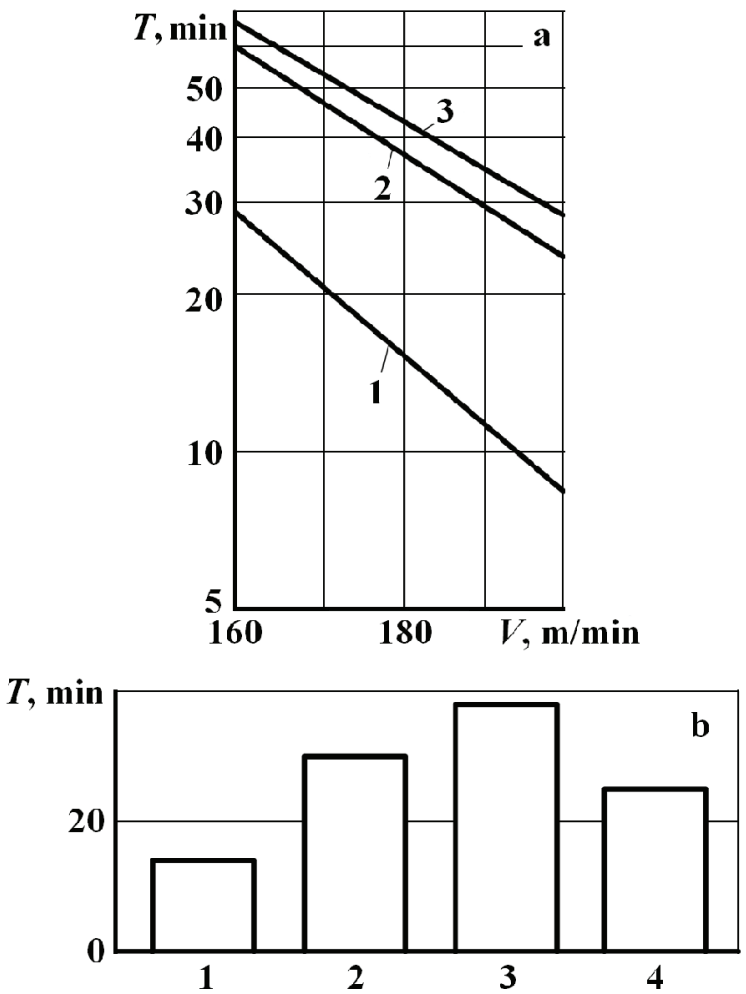

Fig. 2. The dependence of the tool life from the cutting speed (a) and the MK8 plate tool life diagram (b) when turning 38ХГН steel workpieces: $\mathrm{a}-\mathrm{S}=0.15 \mathrm{~mm} /$ rot., $\mathrm{t}=0.5 \mathrm{~mm} ; \mathrm{b}$ $\mathrm{V}=140 \mathrm{~m} / \mathrm{min}, \mathrm{S}=0.3 \mathrm{~mm} /$ rot., $\mathrm{t}=0.5 \mathrm{~mm} ; 1-\mathrm{TiN}, 2$ - TiZrNTiZrAlN, 3 - TiZrN-TiNbAlN, 4 - TiZrN-TiZrCrN

\section{Conclusion}

Multi-layer coatings improve the tool life of carbide tools compared to single-layer coatings. The most efficient are the coatings where the upper layer gives a favorable combination of mechanical properties and residual compressive stresses while the lower layer immediately adjacent to the tool has sufficient adhesion strength.

\section{References}

1. A.S. Vereshchaka, A.A. Vereshchaka, A.I. Bulycheva, Multi-layer Nanodispersive Coatings for Cutters, (Mnogosloynye nanodispersnye pokrytiya dlya rezhushchego instrumenta), Strengthening Technologies and Coatings, (Uprochnyayushchiye tekhnologii i pokrytiya), 5, 33-39, (2014)

2. V.P. Tabakov, Generating Durable Ion-Plasma Coatings for Cutters, (Formirovaniye iznosostoykikh ionno-plazmennykh pokryty rezhushchego instrumenta) (Mashinostroyeniye, 2008)

3. A.S. Vereshchaka, Efficiency of Cutters with Durable Coatings, (Rabotosposobnost rezhushchego instrumenta s iznosostoykimi pokrytiyami) (Mashinostroyeniye, 1993)

4. V.P. Tabakov, A.V. Chihranov, Improving the Efficiency of Carbide Tools by Directed Selection of Durable Coating Composition Parameters, (Povysheniye rabotosposobnosti tverdosplavnogo instrumenta putem napravlennogo vybora parametrov sostava iznosostoykogo pokrytiya), STIN, 3, 14-18, (2016)

5. D.I. Sagitov, Use of Durable Ion Plasma Coatings in Threading, (Primeneniye ionno-plazmennykh iznosostoykikh pokryty na operatsiyakh narezaniya rezby), High-Tech in Mechanical Engineering: Proceedings of the All-Russian Research and Technology Web-Conference, 87-89, (2015)

6. A.A. Vereshchaka, A.S. Vereshchaka, S.N. Grigoryev, Multi-layer Composite Nano-structured Coatings for Tools Used in Demanding Operations, (Mnogosloyno-kompozitsionnye nanostrukturirovannye pokrytiya dlya rezhushchikh instrumentov, rabotayushchikh $v$ tyazhelykh usloviyakh), Strengthening Technologies and Coatings, (Uprochnyayushchiye tekhnologii i pokrytiya), 12, 3-11, (2012)

7. V.S. Goncharov, S.S. Goncharov, N.G. Babenko, Developing the Physical Model of a Durable Tool Complex, (Razrabotka fizicheskoy modeli iznosostoykogo kompleksa rezhushchego instrumenta), Book of Proceedings of the First International Research and Practice Conference On the Research, Development, and Application of High-Tech in Industry, (Issledovaniye, razrabotka i primeneniye vysokikh tekhnology v promyshlennosti), 249-254, (2005)

8. M.Sh. Migranov, Efficiency of Metal Cutting by Tools with Durable Multi-layer Coating (Effektivnost rezaniya metallov pri ispolzovanii instrumenta s mnogosloynym iznosostoykim pokrytiyem), Mechanics and Physics of Proccess on Surfaces and in the Contact of Solids and Parts of Technological and Power Equipment, (Mekhanika i fizika protsessov na poverkhnosti i $\mathrm{v}$ kontakte tverdykh tel, detaley tekhnologicheskogo i energeticheskogo oborudovaniya), 6, 139-144, (2013) 
9. V.N. Gadalov, V.G. Salnikov, D.N. Romanenko, I.V. Shirin, Durable Coatings for Cutters, (Iznosostoykiye pokrytiya dlya rezhushchego instrumenta), Mechanical Engineering Technology, (Tekhnologiya mashinostroyeniya), 7, 26-28, (2011)

10. M. E. Maxims, Durable Coatings and Their Application to Improve the Performance of Cutters, (Iznosostoykiye pokrytiya $i$ ikh primeneniye $v$ povyshenii ekspluatatsionnykh kharakteristik rezhushchego instrumenta), Bulletin of the Moscow State Technical University MAMI, 4 (22), Vol. 2, 27-34, (2014)

11. G.S. Fox-Rabinovich, S.C. Veldhuis, A.L. Kovalev et al, Design and performance of AlTiN and TiAlCrN PVD coatings for machining of hard to cut materials, Surface and coatings technology, 204 (4), 489-496 (2009)

12. M.A. Volosova, V.D. Gurin, Influence of vacuumplasma nitride coatings on contact processes and a mechanism of wear of working surfaces of highspeed steel cutting tool at interrupted cutting, Journal of Friction and Wear, 34 (3), 183-189, (2013)

13. I.V. Blinkov, O.A. Volkhonskii, V.N. Anikin et al, Nanostructured wear-resistant coatings based on multicomponent nitrides and produced by vacuumarc ion-plasma deposition, Protection of Metals and Physical Chemistry of Surfaces, 48 (6), 649-655, (2012)

14. S.S. Gorelik, L.N. Rastorguyev, Yu.A. Skakov, $X$ ray Structure and Electron-Optical Analysis of Metals, (Rentgenostrukturny i elektronnooptichesky analiz metallov) (Metallurgizdat, 1970)

15. V.P. Tabakov, A.V. Chihranov, Determining the Mechanical Properties of Durable Ion Plasma Coatings Based on TiNi, (Opredeleniye mekhanicheskikh kharakteristik iznosostoykikh ionno-plazmennykh pokryty na osnove nitrida titana), Bulletin of Samara RAS Research Center, 12 (4), 292-297, (2010)

16. V.P. Tabakov, S.N. Grigoryev, A.S. Vereshchaka, Principles of Generating and Applying Durable Cutter Coatings, (Printsipy formirovaniya $i$ tekhnologii naneseniya iznosostoykikh pokryty rezhushchego instrumenta) (Ulyanovsk State Technical University, 2012)

17. B.Ya. Mokritskiy, Controlling the Efficiency of Tools by Means of Coating Application, (Upravleniye rabotosposobnostyu instrumenta pri nanesenii pokryty), STIN, 11, 11-15, (2010) 